The freshwater habitats of Chennai (=Madras) and its environs have been surveyed extensively for the past 100 years since Raj in 1910 (Raj 1916). Recent surveys by Knight (2010a) and Knight \& Devi OPEN ACCESS (2010) have revealed that most of the freshwater fish species known from pre-existing data to have inhabited these environs of Chennai have continued to do so; while additional species, of which many are alien, now occur in the area as well, as a result of unmanaged aquaculture and/or unregulated aquarium trade. The aquarium trade has already been responsible for the introduction of a few notorious alien invasive species into the natural waters of Chennai, such as the Loricariidae catfishes of the genus Pterygoplichthys (Knight 2010a; Knight \& Devi 2010), South American and African cichlids such as Amphilophus sp. hybrids (Flower Horns) and Hemichromis sp. (Knight \& Devi 2009a, 2010; Knight 2010a), as well as the South East Asian osphronemid, Trichopodus trichopterus (Daniels \& Rajagopal 2004; Knight 2010a; Knight \& Devi 2010).

During recent (April to June 2014) surveys of the water bodies around Chennai, we recorded two species, Trichopsis vittata and Macropodus opercularis belonging to the family Osphronemidae. Specimens of Trichopsis vittata (Image 1) were collected from an irrigation channel that conveys water from the Chembarampakkam Lake $\left(\sim 13.01^{\circ} \mathrm{N} \& 80.06^{\circ} \mathrm{E}\right)$. The channel, typically, has slow flowing water with a muddy substrate and abundant aquatic vegetation. The specimens that were collected were identified (based on Rainboth 1996) as Trichopsis vittata from the six spines and 27 rays in the anal fin;

\section{ON A RECORD OF TWO ALIEN FISH SPECIES (TELEOSTEI: OSPHRONEMIDAE) FROM THE NATURAL WATERS OF CHENNAI, TAMIL NADU, INDIA}

\author{
J.D. Marcus Knight ${ }^{1}$ \& Shankar Balasubramanian ${ }^{2}$ \\ ${ }^{1}$ Flat L, Sri Balaji Apartments, $7^{\text {th }}$ Main Road, Dhandeeswaram, \\ Velachery, Chennai, Tamil Nadu 600042, India \\ ${ }^{2} 16$, Harinaya Apartments, 78, Oragadam Road, Venkatapuram, \\ Ambattur, Chennai, Tamil Nadu 600053, India \\ ${ }_{1}^{1}$ jdmarcusknight@yahoo.co.in (corresponding author),
} ${ }^{2}$ keepfishingin@gmail.com

the location of dorsal fin origin which was far behind the origin of the pectoral fin; the presence of three spines on the dorsal fin; the absence of the lateral line and the presence of three longitudinal stripes on the body.

The specimens of Macropodus opercularis (Image 2) were collected from the channel that brings water to the Red Hills Lake $\left(\sim 13.16^{\circ} \mathrm{N} \& 80.17^{\circ} \mathrm{E}\right)$. These specimens were identified (based on Freyhof \& Herder 2002) as Macropodus opercularis since the specimen had a forked caudal fin; a spot observed on posterior projection of opercle; presence of posterior anal-fin rays filamentous behind vertical posterior dorsal-fin rays; the presence of 13 dorsal-fin spines and a body with blue bars on a reddish background.

Though the ecological impacts of neither Trichopsis vittata orMacropodusopercularishavebeen documented, it is quite obvious that like $T$. trichopterus, they would also compete for niche space with native species such as Trichogaster lalius and Pseudosphromenus cupanus (Knight 2010b). As both T. vittata and M. opercularis are

DOI: http://dx.doi.org/10.11609/JoTT.04135.7044-6

Editor: W. Vishwanath, Manipur University, Imphal, India.

Date of publication: 26 March 2015 (online \& print)

Manuscript details: Ms \# 04135 | Received 26 August 2014 | Final received 08 December 2014 | Finally accepted 24 February 2015

Citation: Knight, J.D.M. \& S. Balasubramanian (2015). On a record of two alien fish species (Teleostei: Osphronemidae) from the natural waters of Chennai, Tamil Nadu, India. Journal of Threatened Taxa 7(3): 7044-7046; http://dx.doi.org/10.11609/JoTT.04135.7044-6

Copyright: (@ Knight \& Balasubramanian 2015. Creative Commons Attribution 4.0 International License. JoTT allows unrestricted use of this article in any medium, reproduction and distribution by providing adequate credit to the authors and the source of publication.

Funding: None.

Competing Interest: The authors declare no competing interests.

Acknowledgements: We acknowledge, with gratitude, the support provided by K. Venkataraman, Director, Zoological Survey of India, Kolkata; K. Ilango (Officer in Charge) and Jayasree Thilak (Scientist-C), of the Southern Regional Centre, Zoological Survey of India, Chennai. We also thank Andrew Rao profusely for sharing his field notes and Athreyan Padmanabhan, Bens Raj and Rajasekaran Ramachandran for assisting us with the field survey. 


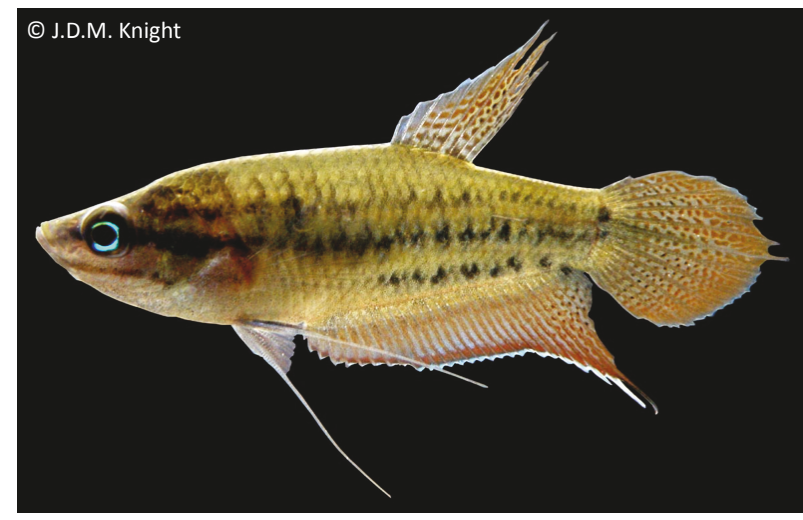

Image 1. Trichopsis vittata collected from Chembarampakkam Lake, Chennai.

air-breathers and exhibit parental care, they will be able to ensure better survival of their young, even in stagnant and polluted water systems with high biological oxygen demand (BOD) where other fish species may not be able to survive and reproduce.

It is relevant to note that both Trichopsis vittata and Macropodus opercularis are known to establish viable populations in non-native ranges. Trichopsis vittata which is native to Southeast Asia (Rainboth 1996) has established a viable population in Florida, United States of America, since the early 1980s (Courtenay \& Stauffer 1990) and has thrived for decades as their extermination was practically impossible (Schofield \& Pecora 2013). Similarly, M. opercularis also a native to Southeast Asia and China (Freyhof \& Herder 2002) has established a viable population in Florida, United States of America, since the early 1940s (Myers 1940). Moreover, M. opercularis, has also established non native populations in Singapore and Japan (Wang et al. 1999). It is rather interesting to note that, Florida, Japan and Singapore are all hubs of ornamental fish trade, similar to Chennai. This highlights the fact that such regions are more likely to be colonized by exotic aquarium species due to the higher probability of such species being released into the wild.

The propagule pressure theory clearly demonstrates the relationship between the frequency of fish sold in aquarium stores and their introduction and establishment in freshwater habitats (Duggan et al. 2006). Though it is quite convincing that both $T$. vittata and $M$. opercularis were introduced into the natural waters of Chennai, contrary to the propagule pressure theory, both these species are not very common in the aquarium stores in the city, with $T$. vittata being completely absent from local aquarium trade for the past five years (2010-2014). Though the aquarium trade is, no doubt, responsible for

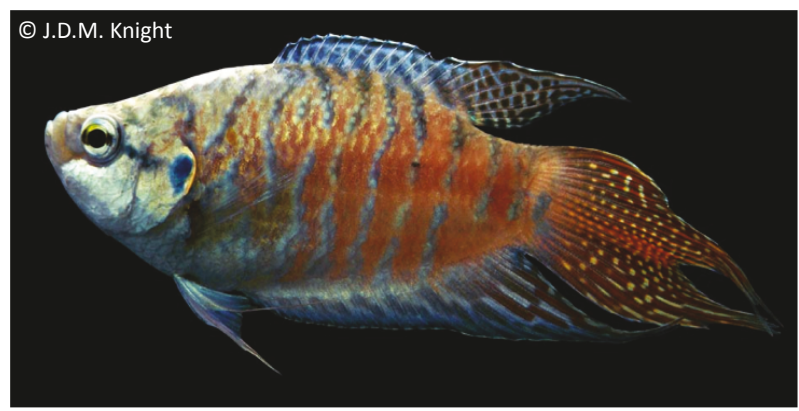

Image 2. Macropodus opercularis collected from Red Hills Lake, Chennai.

many exotic fish introductions into the natural waters of Chennai, it is not the only source. It has already been speculated that the river linking projects have brought in some species such as Badis badis (Knight \& Devi 2009b) and Pethia gelius (Knight 2010c) which were previously unknown in this region into the river system. Species like Osteobrama cotio, the presence of which were earlier reported from the Eastern Ghats and Andhra Pradesh (Devi \& Indra 2003; Chandrasekhar 2004) has established a population in Chembarampakkem Lake, Chennai (Knight \& Devi 2010). Recently, one other similar species, Pethia phutunio (Image 3), which was earlier not known to inhabit Chennai and its environs (Knight 2010a; Knight \& Devi 2010) is now frequently encountered in water bodies around Chennai. There is an unconfirmed report of a well established non-native population of Trichopsis vittata in Dhaka, Bangladesh (Andrew Rao pers. com. 2014). The role of inter-basin water transfer playing a role in introducing non-native species into an ecosystem cannot be ruled out.

It is relevant to note at this point that unmanaged aquaculture also has played a role in introducing exotic aquarium species into the natural waters of Chennai. A good example is the introduction of the exotic Redbellied Pacu Piaractus brachypomus into the natural waters of Chennai (Image 4). Though P. brachypomus was introduced to Indian waters from Bangladesh during the years 2003 and 2004 as a result of the aquarium trade (Chatterjee \& Mazumdar 2009), recent large scale aquaculture of this species as a candidate food fish under the name 'Red Pomfret or Freshwater Pomfret' has paved way for this species to establish natural populations across India, right from the rivers in Tripura (Datta \& Nandeesha 2006), Dimbhe Reservoir, Maharashtra (Singh \& Lakra 2011), Godavari River, Andhra Pradesh (Johnson et al. 2014), to Periyar River and Chalakudy River, Kerala (Dahanukar et al. 2011; Unmesh et al. 2012). We also note in passing that the 'Piranha' reported by Kumar 


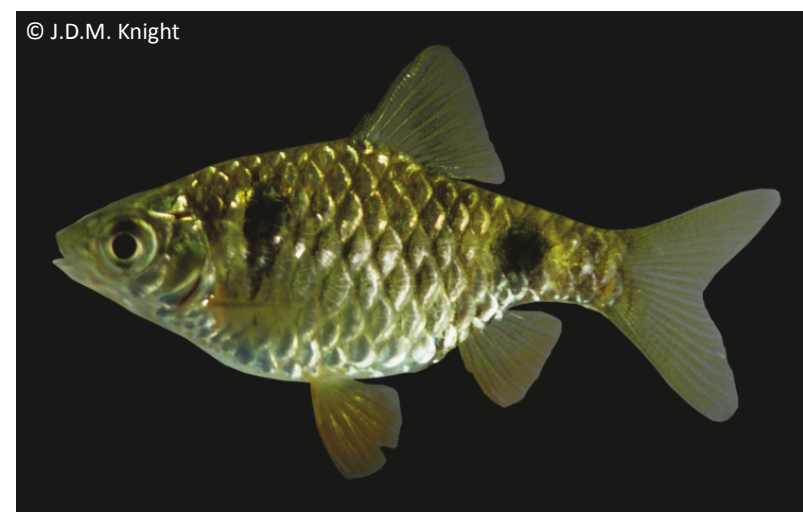

Image 3. Pethia phutunio collected from the Red Hills Lake, Chennai.

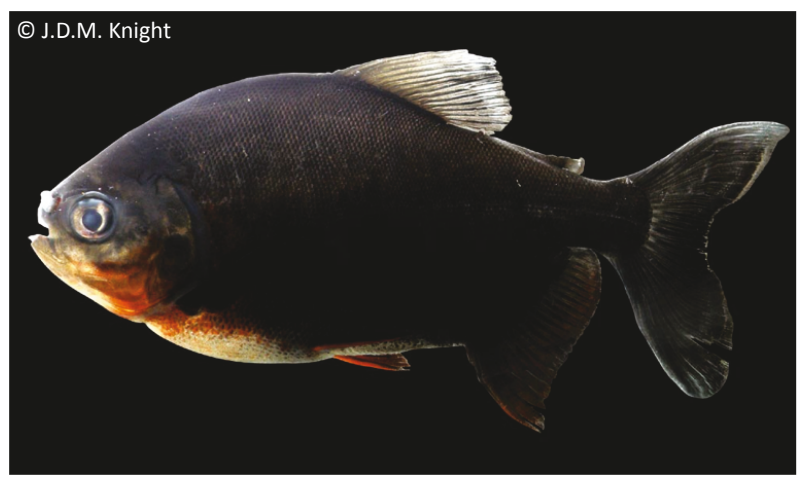

Image 4. Piaractus brachypomus collected from Poondi Lake, Chennai.
(2000) and Johnson et al. (2014) are misidentifications of the Red-bellied Pacu (Piaractus brachypomus).

One-third of the aquatic species on the IUCN Invasive Species Specialist Group's list of the 100 of the world's worst invasive species (Lowe et al. 2000) are from aquarium or ornamental releases. Unless stringent measures are adopted to monitor the aquarium fish trade and aquaculture for the release of alien species into our waters; man-made tanks and lakes will soon emerge as breeding grounds for alien invasive fish that will eventually eradicate our native freshwater fishes.

\section{References}

Chandrasekhar, S.V.A. (2004). Fish fauna of Hyderabad and its environs. Zoos' Print Journal 19(7): 1530-1533; http://dx.doi.org/10.11609/ JoTT.ZPJ.900.1530-3

Chatterjee, N. R. \& B. Mazumdar (2009). Induced breeding of Pacu (Piaractus brachypomus) in captivity with pituitary extract. Aquaculture Asia 14(2): 23.

Courtenay, W.R. Jr. \& J.R. Stauffer, Jr. (1990). The introduced fish problem and the aquarium fish industry. Journal of the World Aquaculture Society 21(3):145-159.

Dahanukar, N., R. Raghavan, A. Ali, R. Abraham \& C.P. Shaji (2011). The Status and distribution of freshwater fishes of the Western ghats pp. 21-48. In: Molur, S., K.G. Smith, B.A. Daniel \& W.R.T. Darwall (Comp.). The Status and Distribution of Freshwater Biodiversity in the Western Ghats, India. Cambridge, UK and gland, Switzerland: IUCN, and Coimbatore, India: Zoo Outreach organization, 116 pp.

Datta, M.K. \& M.C. Nandeesha (2006). Pacu (Piaractus brachypomus), an acid water loving exotic finfish, enters Indian aquaculture scene. Fishing Chimes 26(6): 10-12.

Daniels, R.J.R. \& B. Rajagopal (2004). Fishes of Chembarampakkam Lake - a wetland in the outskirts of Chennai. Zoos' Print Journal 19: 1481-1483; http://dx.doi.org/10.11609/JoTT.ZPJ.1041.1481-3

Duggan, I.C., C.A.M. Rixon \& H.J.M. Isaac (2006). Popularity andpropagule pressure: determinants of introduction and establishment of aquarium fish. Biological Invasions 8: 377-382.

Freyhof, J. \& F. Herder (2002). Review of the paradise fishes of the genus Macropodus in Vietnam, with description of two species from Vietnam and southern China (Perciformes: Osphronemidae). Ichthyological Exploration of Freshwaters 13(2): 147-167.

Johnson, J.A., R. Paromita \& K. Sivakumar (2014). Report of new invasive fish, Red-bellied Piranha Pygocentrus nattereri in Godavari
River, Andhra Pradesh. MIN, The Newsletter of the South Asia Office of the IUCN SSC/WI Freshwater Fish Specialist Group, 2, 8-10.

Knight, J.D.M. (2010a). Addressing the wallacean shortfall: an updated Checklist of Icthyofauna of Chembarampakkam Tank. Taprobanica 2(1): 25-29; http://dx.doi.org/10.4038/tapro.v2i1.2704

Knight, J.D.M. (2010b). Invasive ornamental fish: a potential threat to aquatic biodiversity in peninsular India Journal of Threatened Taxa 2(2): 700-704; http://dx.doi.org/10.11609/JoTT.o2179.700-4

Knight, J.D.M. (2010c). On a record of Puntius gelius (Hamilton, 1822) (Teleostei: Cypriniformes: Cyprinidae) from Tamil Nadu. Journal of Threatened Taxa 2(3): 786-787; http://dx.doi.org/10.11609/JoTT. 02298.786-7

Knight, J.D.M. \& K.R. Devi (2009a). On a record of Amphilophus trimaculatum (Günther) (Teleostei: Perciformes: Cichlidae) in the natural waters of Tamil Nadu, India. Journal of the Bombay Natural History Society 106(3): 347-348.

Knight, J.D.M. \& K.R. Devi (2009b). On a record of Badis badis (Hamilton) (Teleostei: Perciformes: Badidae) from TamilNadu. Journal of the Bombay Natural History Society 106(2): 329-330.

Knight, J.D.M. \& K.R. Devi (2010). Species persistence: a re-look at the freshwater fish fauna of Chennai, India. Journal of Threatened Taxa 2(12): 1334-1337; http://dx.doi.org/10.11609/JoTT.o2519.1334-7

Kumar, A.B. (2000). Exotic fishes and freshwater fish diversity. Zoos' Print Journal 15(11): 363-367; http://dx.doi.org/10.11609/JoTT. ZPJ.15.11.363-7

Lowe, S., M. Browne \& S. Boudjelas (2000). 100 of the world's worstinvasive alien species. IUCN/SSC Invasive Species Specialist Group, Auckland, New Zealand, 11pp

Myers, G.S. (1940). An American Cyprinodont fish, Jordanella floridae, reported from Borneo, with notes on the possible widespread introduction of foreign aquarium fishes. Copeia 267-268.

Schofield P.J. \& D.J. Pecora (2013). Croaking Gourami Trichopsis vittata (Cuvier, 1831), in Florida, USA. Biolnvasions Records 2(3): 247-251; http://dx.doi.org/10.3391/bir.2013.2.3.12

Singh, A.K. \& W.S. Lakra (2011). Risk and benefit assessment of alien fish species of the aquaculture and aquarium trade into India. Reviews in Aquaculture 3: 3-18.

Rainboth, W.J. (1996). Fishes of the Cambodian Mekong. FAO Species Identification Field Guide for Fishery Purposes. FAO, Rome, 265pp.

Raj, S.B. (1916). Notes on the freshwater fish of Madras. Records of the Indian Museum XII (Part VI): 249-294.

Devi, K.R. \& T.J. Indra (2003). An updated checklist of Ichthyofauna of Eastern Ghats. Zoos' Print 18(4): 1067-1070; http://dx.doi. org/10.11609/JoTT.ZPJ.18.4.1067-70

Unmesh, K., D. Apte \& R. Raut (2012). Invasion in our rivers. Hornbill April-June, 42-45.

Wang, T.Y., C.S. Tzeng \& S.C. Shen (1999). Conservation and Phylogeography of Taiwan Paradise Fish, Macropodus opercularis Linnaeus. Acta Zoologica Taiwanica 10(2): 121-134. 